\title{
A REVIEW OF THE INVASIVE, BIOLOGICAL AND BENEFICIAL CHARACTERISTICS OF AQUATIC SPECIES EICHHORNIA CRASSIPES AND SALVINIA MOLESTA
}

\author{
KOUTIKA, L-S ${ }^{1} *-$ RAINEY, H. J. ${ }^{2}$ \\ ${ }^{1}$ Centre de Recherche sur la Durabilité et Productivité des Plantations Industrielles (CRDPI) \\ B.P. 1291, Pointe-Noire, Republic of the Congo. \\ ${ }^{2}$ Wildlife Conservation Society, 2300 Southern Boulevard, 10460 Bronx, NY, USA. \\ (phone: +242-068-133-452) \\ *Corresponding author \\ e-mail:ls_koutika@yahoo.com \\ (Received 23 ${ }^{\text {rd }}$ Sept 2013; accepted $14^{\text {th }}$ Aug 2014)
}

\begin{abstract}
The aquatic invasive plant species Eichhornia crassipes and Salvinia molesta originated in the Neotropics (Bolenz et al., 1990; Tipping and Center, 2005). Based on environmental, economic and human problems, E. crassipes and S. molesta are ranked first and second places respectively on a list of the world's most problematic aquatic weeds (Holm et al., 1977; Barrett, 1989). This review paper presents the impacts of these two species on the environment, mainly in aquatic ecosystems of the tropics and subtropics, and also their use in societies and agro-industry with particular reference to their distribution and environmental impacts in ecosystems.
\end{abstract}

Keywords: Eichhornia crassipes, Salvinia molesta, biological control, chemical control, mechanical control.

\section{Introduction}

This paper is reviewing the positive and negative impacts of Eichhornia crasspes and Salvinia molesta, two of the world's worst aquatic tropical weeds to strengthen and improve the knowledge and use of these species in the areas they invaded. This review provides an overview of agricultural and ecological uses of the two species based on the findings made during the last decades.

The worst tropical aquatic weeds are mainly native to a vast biogeographic unit comprising South and Central America, the Caribbean and southern Mexico, amongst them Eichhornia crassipes and Salvinia molesta (Barreto et al., 2000). Due to their aggressive invasive characteristics much research has been focused on identifying biological control agents in their native area (Holm et al., 1977; Barreto et al., 2000).

Even though, both species have induced several negative impacts on the environment (Room, 1988), their positive impacts have been also evaluated (Vandecasteele et al., 2005). E. crassipes is the neotropical aquatic weed that has received the greatest attention from plant pathologists (Barreto et al., 2000), and is amongst seven aquatic weeds (i.e., Eichhornia polystachya, E. crassipes, E. azurea, Paspalum repens, $P$. stratiotes, $P$. spectabile and Typha domingensis) for which a survey of mycobiota has been made in Brazil.

The review of Villamagna and Murphy (2009) gives details of the ecological and socio-economic negatives changes resulting from invasion by E. crassipes. This review gives interesting details on impacts on water quality, the community composition of zooplankton, macroinverterbrates, fish and birds, and socio-economic conditions.

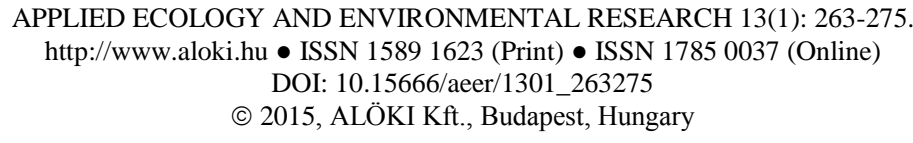


Henry-Silva and Camargo (2006) evaluated the efficiency of E. crassipes and $S$. molesta to threaten effluents from fishing farming from Nile tilapia culture ponds.

Moreover, both species have positive impacts. E. crassipes can also be used for phytoremediation and biogas (Singhal and Rai, 2003; Zimmels et al., 2006). Oliver (1993) and more recently McFarland et al. (2004) reviewed many aspects of the ecological and socio-economic effects of invasion by $S$. molesta. Even though $S$. molesta is not widely used for phytoremediation and biogas compared to E. crassipes, and regardless of their invasive characteristics, E. crassipes and $S$. molesta may have beneficial agricultural and ecological uses (Oliver, 1993; McFarland et al., 2004).

Vandecasteele et al. (2005) argued that aquatic plant based treatment systems are low cost technologies which may be adopted by developing countries for recycling and treating wastewater mainly contaminated by heavy toxic metals. E. crassipes was more efficient in total phosphorus removal $(82 \%)$ and total nitrogen removal $(46.1 \%)$ than $S$. molesta which removed only $72.1 \%$ of total phosphorus and $42.7 \%$ of total nitrogen, while the control only removed 50.3\% (total phosphorus) and total nitrogen (22.8\%). The authors concluded that the water of treated effluents may be reused in aquaculture activity. The authors also concluded that considering the potential for using the biomass of aquatic macrophytes as plant compost, biogas production and animal feed, $E$. crassipes should be preferred as treatment for aquaculture effluents. From a synthesis of 192 lakes of tropical and subtropical aquatic systems, Huszar et al. (2006) revealed P as a better predictor of phytoplankton biomass (Huszar et al., 2006).

Biomass size and the concentration of nutrients in plant tissues both influenced the potential absorption of nutrients by aquatic macrophytes. S. molesta is less efficient in the removal of nutrients than the larger E. crassipes because of its lower biomass. $S$. molesta biomass reached the maximum of its carrying capacity in the first month of experiment while E. crassipes increased biomass for a number of months showing its greater ability of absorption. Thus, after macrophyte treatment it is possible to reuse the water recovered from effluent from fish farms and to release it into aquatic ecosystems thus avoiding eutrophication (Henry-Silva and Camargo, 2006).

\section{Eichhornia crassipes}

\section{Origin, morphology and dispersal}

E. crassipes (Martius) Solms (Pongtederiaceae), commonly called water hyacinth, is a floating plant native to the Neotropics originating in the Amazon basin in Brazil (Bolenz et al., 1990; Table 1). Center et al. (1987) described E. crassipes as a plant having an individual rosette with an erect, free floating, stoloniferous and perennial herb bearing a whorl of 6-10 sequentially produced succulent leaves on short vertical stem. The species has become a widespread pantropical weed and is recognized as the world's worst aquatic weed (Holm et al., 1977). E. crassipes spread from its native South America and occurs in lakes, slow moving rivers and swamps of the world between $40^{\circ} \mathrm{N}$ and $40^{\circ} \mathrm{S}$ (Center, 1994).

The species gained attention as an ornamental plant because of its attractive purple flower and more than a century ago, E. crassipes was first distributed by gardeners and horticulturists and introduced from South America into North America during the late $19^{\text {th }}$ century (Center et al., 2005). Thereafter spread to different tropical and subtropical areas of the world. According to Twongo and Balirwa (1995) E. crassipes was introduced in Africa to the River Nile in the 1870s and it is believed to have been 
present in Lake Victoria since the early 1980s. It has become widespread across the lake since this date and $80 \%$ of the Ugandan coast line of Lake Victoria was covered in the 1995. In West Africa, it was first observed in the late 1970s and became a major problem in the late 1980s (De Groote et al., 2003). The species is widespread present in Mali, Burkina Faso, Niger, Côte d'Ivoire, Togo, Benin and Nigeria, and has negatively affected the highly productive coastal creek and lagoon systems, from which many people derived their livelihoods (Julien et al., 1999). According to Mbati and Neuenschwander (2005), E. crassipes invaded the Congo basin much earlier than western Africa in the 1950s. There are even reports that E. crassipes was deliberately introduced to the upper reaches of the Likouala-aux-Herbes River, Congo-Brazzaville to prevent access by boats from warring villages approaching other villages.

\section{Reproduction}

E. crassipes produces huge numbers of seeds (Barrett, 1980) and its expansion throughout the tropics has been favoured by its extremely fast and uncontrolled plant growth and the robustness of its seeds (Aweke, 1993; Malik, 2007). Its average annual production is of 50 dry (ash-free) tons per hectare per year, which qualifies the species as one of the most productive plants in the world (Abbasi and Ramasamy, 1999) and it has become the major floating waterweed of tropical and subtropical regions of the world (Aweke, 1993; Gunnarson and Petersen, 2007; Malik, 2007). The species reproduces sexually by seeds and asexually by budding and stolen production; for rapid expansion asexual reproduction is more important (Watson and Cook, 1987; Verma et al., 2003). The optimum $\mathrm{pH}$ for its growth is 6-8 and the species persists over a wide range of temperature 1 to $40^{\circ} \mathrm{C}$ with optimum growth at $25-27.5^{\circ} \mathrm{C}$. Its growth rate increases with the increase of water nitrogen contents, but salinity levels of 6-8\% are lethal to the species (Malik, 2007).

E. crassipes causes several environmental and socio-economic problems (Table 1): (i) its dense floating mass hinder fishing and transport; (ii) it interferes with the use of water for drinking purposes, irrigation and electric power generation; and (iii) its negative effects on biodiversity. This has caused a reduction of fish biomass, obstruction of shipping routes, losses of water in irrigation systems due to higher evaporation and increased sedimentation by trapping silt particles. Invasion of water hyacinth has had great environmental and socio-economic impacts in Lake Victoria (Williams et al., 2005; Twongo et al., 2005; Katerrega and Sterner, 2007) and many other tropical lakes (Mironga, 2004). Keterrega and Sterner (2007) reliably estimated the extent of water hyacinth coverage for the period 1990-2001 and showed the greatest coverage of Lake Victoria by E. crassipes occurred after 1995 and its reduction after 1997.

\section{Nutrient contents}

E. crassipes can be rich in nitrogen (up to $3.2 \%$ of dry matter) and has a $\mathrm{C} / \mathrm{N}$ ratio of around 15 (Gunnarson and Petersen, 2007). E. crassipes is a rich source of mineral contents and can serve as suitable economic feed (Lata and Veenapani, 2010). The authors found that dry matter of E. crassipes consisted of $5.2 \% \mathrm{~N}, 0.22 \% \mathrm{P}, 2.3 \% \mathrm{~K}$, $0.36 \% \mathrm{Ca}, 280 \mathrm{ppm}$ of $\mathrm{Fe}, 45 \mathrm{ppm}$ of $\mathrm{Zn}, 2 \mathrm{ppm}$ of $\mathrm{Cu}$ and $332 \mathrm{ppm}$ of $\mathrm{Mn}$. 


\section{Positive use}

Besides its fast-growing invasive characteristics, E. crassipes may also have beneficial purposes (Table 1). Ebel et al. (2007) determined the sodium cyanide phytotoxicity and removal capacity of E. crassipes: The authors found that this species can remove cyanide from water because of its high biomass production, wide distribution and tolerance to cyanide and metals. In fact, $2 \mathrm{~g}$ of plant material needed about $20 \mathrm{~h}$ to degrade $50 \%$ of the cyanide applied and $>50 \mathrm{~h}$ to eliminate the cyanide completely at $2 \mathrm{mg}^{-1}$. Ebel et al. (2007) found that E. crassipes may be useful in treating effluents from small-scale gold mines. Similarly, its enormous biomass production rate, its high tolerance to pollution and its heavy-metal and nutrient absorption capacities permit its use in wastewater treatment ponds in mining areas of its native continent, South America (Ebel et al., 2007). The experiments conducted by Caldelas et al. (2009) of the combined exposure to excess nutrients and $\mathrm{Hg}$, have confirmed the ability of the species in the heavy metal phytoremediation of eutrophic water.

E. crassipes may be used in composting or vermicomposting. Gajalakshmi et al. (2002) demonstrated the feasibility of high-rate composting or worm-composting systems. Gunnarson and Petersen (2007) identified various beneficial effects of $E$. crassipes in composting since the species is rich in nitrogen (up to $3.2 \%$ of dry matter). E. crassipes can be used as a substrate for compost or biogas production and the byproduct of this can be used as fertilizer, since the sludge from the biogas contains almost all of nutrients of the substrate. The use of water hyacinth compost on different crops has resulted in improved yields. Its abundant growth and high concentrations of nutrients give $E$. crassipes great potential as a fertilizer, which is particularly pertinent for the nutrient deficient soils of the tropics. In addition, its high protein content makes it possible to be used as fodder for livestock. In fact, Dada (2002) argued that the use of sundried E crassipes for raising goats at levels up to $40 \%$ of diet is beneficial. The authors found E. crassipes (leaves and stalk) contained $80 \%$ of dry matter of which 10.8 $\%$ of crude protein, $2.3 \%$ of ether extract, $14.06 \%$ of ash and $18 \%$ of crude fibre.

The species has a valuable role in the treatment of wastewater (Brix, 1997). Zimmels et al. (2006) showed the effectiveness of sewage purification by E. crassipes in the laboratory. It reduced indicators of sewage such as the biochemical oxygen demand, the chemical oxygen demand, the total suspended solids and turbidity to low levels which permitted the use of purified water for irrigation of tree crops. Their results have shown that the use of this free water surface flow system and its low maintenance system for treatment of urban and agriculture sewage is a viable option. Kutty et al. (2009) argued that $E$. crassipes is capable of removing up $49 \%$ of chemical oxygen demand, $81 \%$ of ammonia, $67 \%$ of phosphorus and $92 \%$ of nitrate from the municipal wastewater treatment effluent.

E. crassipes may be also be used in agro-industry and industry (Verma et al., 2007). Xia and Ma (2006) investigated the potential of water hyacinth to remove a phosphorus pesticide ethion from water. Accumulated ethion in live water hyacinth plant was lower in shoots and roots, suggesting that plant uptake and phytodegradation might be the dominant process for ethion degradation of agroindustrial wastewater polluted with ethion. 


\section{Negative impacts}

The growth of floating macrophytes is a well-known undesirable consequence of eutrophication (Brendonck et al., 2003). Shallow lakes can be very clear with abundant submerged plants or very turbid because of the high concentration of phytoplankton and suspended particles (Scheffer et al., 2003). Cooke et al. (1993) have shown that in small aquatic ecosystems, the main control measure used mainly in tropical areas is the mechanical removal of free-floating macrophytes. However, macrophyte control often induces unwanted side-effects; the removal of one nuisance species, either native or exotic, may enhance the successful colonisation by another more aggressive species as was observed in aquatic zones by Cooke et al. (1993).

\section{Control}

Until recently, attempts to control or destroy E. crassipes by chemical, biological, mechanical or hybrid methods had had limited success (Abbasi et al., 1997), in part because it is one of the most productive and hardly of all weeds (Abbasi and Ramasamy, 1999; Malik, 2007). However, it is very likely that almost all alien invasive plant species will have natural enemies or predators in their original ecosystem (e.g. Lee, 1979). Malik (2007) identified the agents and limitations of three main method of control of water hyacinth: (i) biological control by insects such as Neochetina eichhorniae, N. bruchi etc...; allopathic plants, lantana, fungal pathogens (Alternaria eichhorniae): these may not cause a sufficient reduction in the area affected by $E$. crassipes and could allow a possible resurgence in growth by E. crassipes (Julien and Griffiths, 1998; Saxena, 2000; Kauraw and Bhan, 1994; Babu et al., 2004); (ii) various chemical products (including 2,4 dichlorophenoxyacetic acid and complexed copper, 2,4 D Amine spray or Endothall dipotassium salts): these have limitations such as cost; are not suitable for controlling large infestations and will affect the environment (Westerdahl and Getsinger, 1988; Olaleye and Akinyemiju, 1996); and (iii) physical control such as manual and mechanical removal which have physical limitations and are labour intensive which could involve health risks (Smith et al., 1984) or might be expensive and energy intensive (Harley et al., 1997). These three main methods are considered in more detail below.

Efforts have been made to collect arthropods for the biological control of $E$. crassipes (Harley, 1990), although it has proved difficult to assess the effects of these species on the plant. Ten species were selected for biological control of E. crassipes (Charudattan, 1996) of which six were considered to be of potential practical use. One species believed to have outstanding potential for mycoherbicide development is alternative eichhorniae Nag Raj and Ponnappa, a species widely spread in Asia and Oceania, but not known from the Neotropics (Charudattan, 1996).

Julien and Griffths (1998) selected 7 arthropods from the Neotropics which attack E. crassipes in its native region and released them in 33 countries to assess the effectiveness of each for biocontrol purposes. Among these, two weevils Neochetina eichhorniae Warner and N. bruchi Hustache (Coleoptera, Curculionidae), appeared to cause a substantial reduction of the water hyacinth in countries where they have been, including African countries such as Sudan, Benin, Côte d'Ivoire, Ghana, Nigeria, Burkina Faso, the countries around Lake Victoria and in Southern Africa (De Groote et al., 2003). 
Between 1991 and 1993, three natural enemies (two weevil species and one moth) that feed exclusively on water hyacinth, were released in southern Benin. Six years later, i.e., in 1999, the survey showed that E. crassipes, although not eliminated, had been reduced from a serious pest to one of minor or moderate importance (De Groote et al., 2003). The authors reported that at the peak of the investigation E. crassipes had reduced national annual income by approximately US\$84 million, and biological control using these species increased income by US\$30 million per year and the total cost of the control program was of US\$2.09 million.

The South American Neochetina spp. weevil has a positive impact on water hyacinth. They have been used successfully throughout the world in the countries such as the USA, Australia, India (Julien et al., 1999). Williams et al. (2005) reviewed the effects of Neochetina spp on reduction of E. crassipes in Lake Victoria and argued that the wet and cloudy weather of $1997 / 1998$ played a major part by accelerating the decline of E. crassipes through reduced light on its growth throughout the lake basin. Williams et al. (2005) argued that the improvement of light climate since 1997/1998 and the availability of nutrients may induce the resurgence and proliferation of $E$. crassipes in the Lake Victoria. However, the weed remains sparse on the lake.

Biological control of E. crassipes has been conducted in many part of the world. Center et al. (1999) showed that sustained herbivory of E. crassipes reduced proportionately biomass and floral structures. Normally E. crassipes will out-compete other floating aquatic plants; Center et al. (2005) measured E. crassipes biomass production and compared to Pistia stratiotes and found that E. crassipes biomass yield was 41 times that of Pistia stratiotes. However when controlled the species with weevils, Center et al. (2005) argued that herbivory directly and indirectly affected plant performance by altering competition between the two invasive plant species. The competitive response depended upon the herbivore species and availability of nutrients. In addition, Center and Dray (2010) argued that improved nutritional quality of the host plant could lead to more effective biological.

Julien et al. (1999) argued that the use of chemical control might be effective but it had negative side effects on the environment. Cadmium (Cd), a widespread non essential toxic heavy metal, emitted in the environment in different ways (power station, heating systems, metal-working industries etc...), di Toppi et al. (2007) was an effective chemical control of E. crassipes. The authors found that E. crassipes accumulated $\mathrm{Cd}$ in leaves. Many countries such as Thailand, South Africa and Kenya have used mechanical control of E. crassipes either by hand or machine, although it is considered expensive and not very effective (Cilliers, 1991).

\section{Salvinia molesta}

\section{Origin, morphology and dispersal}

Salvinia molesta D.S. Mitchell (Salviniaceae) is a sterile rhizomatous plant, very suitable for demographic studies because of its free-floating habit which enables non destructive access to 'rhizomes' and 'roots' (Room, 1988). S. molesta also called giant salvinia, is a problematic aquatic weed indigenous to south-eastern Brazil and occurs between latitudes 24 and 32 degrees south (Forno and Harley, 1979, Table 1). This species, which is a free-floating fern, quickly covers and dominates stagnant and slow flowing water systems and can choke waterways. The species floats on still and slowmoving water and can grew rapidly to cover the entire water surface with a thick mat of 
vegetation. The vegetation shades out any submerged plant life and impedes oxygen exchange making unsuitable for animals lives and reducing the natural beauty and biodiversity of wetlands. The species is now widespread across the world, in Africa, Australia, Asia and the southern part of North America (Jacano, 1999; McFarland et al., 2004; Owens et al., 2005; Tipping and Center, 2005).

\section{Reproduction}

S. molesta spreads at rapid rate by vegetative reproduction. S. molesta floats with wind or water currents to uninfected waters. It can grow and propagate vegetatively. It reproduces solely from production and loss of ramets on branched rhizomes. The ramets can survive independently but they are held together in colonies until rhizomes break (Room, 1988). When the species is introduced to new habitats, it produces colonizing stage plants which have thin stems and fragment easily, to produce further new plants. The species is a highly aggressive and competitive species. Kammathy (1968) argued that the species successfully competes with and even replaces water hyacinth and water lettuce. According to Owens et al. (2004), temperature is probably the greatest factor limiting $S$. molesta growth, survival and spread. In fact, the species appears to be unable to survive in locations where ice forms for extended periods (Owens et al., 2004). Owens et al. (2005) also found that S. molesta biomass was produced over 2-fold increase at the lower $\mathrm{pH}$.

In the northern part of the Republic of the Congo, Mbati and Neuenschwander (2005) also observed that $S$. molesta was more aggressive than E. crassipes. S. molesta invaded the Congo basin 10 years later than E. crassipes in the 1960s. S. molesta was found in the main river in unshaded waters of the country, not apparently found in shaded forested areas. Despite this, it does not form large monospecific mats, indeed it was rarely seen in groups of more than 2-3 'individuals'. It is possible that it was also able to grow in the small affluent, but here it was not greatly evident because of the abundance of E. crassipes. Again, the ecological characteristics of the waters of the swamps may prevent this species becoming a widespread pest.

\section{Nutrient contents}

According to Leterme et al. (2010), dry matter of $S$. molesta contained $132 \mathrm{~g} \mathrm{~kg}^{-1}$ of crude protein, $130 \mathrm{~g} \mathrm{~kg}^{-1}$ of ash, $42 \mathrm{~g} \mathrm{~kg}^{-1}$ of ether extract and $135 \mathrm{~g} \mathrm{~kg}^{-1}$ of lignin.

\section{Positive use}

Compared to E. crassipes, which is more often used for phytoremediation (Malik et al., 2007), S. molesta presents less of an environmental challenge (Table 1). S. molesta has been used as a compost and mulch and as supplement to folder for livestock in some Asian countries (Oliver, 1993). The species could be used as feed ingredients for sows (Leterme et al., 2010). However the authors argued that S. molesta does not seem to present any additional advantage from existing feed ingredients because of its low crude protein $\left(132 \mathrm{~g} \mathrm{~kg}^{-1}\right)$ compared to Azolla filiculoides ( $\left.>220 \mathrm{~kg}^{-1}\right)$, which is floating ferns with symbiotic $\mathrm{N}_{2}$-fixing cyanobacteria that are used in Asia to fertilise rice fields.

Chantiratikul et al. (2009) found that $S$. molesta had higher contents of total phenolic and antioxidant than E. crassipes with naringinin as the main phenolic compounds while myricetin, vanillin, kaempferol and quercetin were present in low concentrations. 
Therefore, the authors argued that $S$. molesta can be utilized as a source of aquatic weeds antioxidant with a potential use in feed animals.

Some studies have also reported $S$. molesta suitability in papermaking and generation of biogas (Thomas and Room, 1986) and in treating sewage effluent (Finlayson et al., 1982). However McFarland et al. (2004) reported that none of these efforts has led to large scale utilization, probably due to high costs associated with labour and machinery.

\section{Negative impacts}

$S$. molesta combines a high growth rate with a slow rate of decomposition to reduce nutrients available for absorption by other plants (Table 1). Thus S. molesta potentially alters the natural nutrient dynamics of water bodies which it colonizes (Shrama and Goel, 1986). S. molesta is an important host of Mansonia mosquitoes, which serve as one of the main vectors of rural elephantiasis (Pandro and Soerjani, 1978). Other diseases including encephalitis, malaria and dengue fever are caused by mosquitoes sheltering in S. molesta (Creagh, 1992). S. molesta can also have other detrimental effects on the ecology of aquatic systems by restricting light penetration and exchange of gases between the water and atmosphere (McFarden et al., 2004).

\section{Control}

There is a possibility of biological control using the species Cyrtobagous salvinae, the insect attacks buds and young ramets of the plant. Julien and Griffiths (1998) have showed that Cyrtobagous salviniae successful controlled S. molesta in 13 countries. The stochastic simulation model accurately mimicked branching growth of plants in the field and was predicted to achieve biological control of infestations of S. molesta with a population density of 300 adults and 900 larvae of Cyrtobagous salviniaceae per square metre. Two fungal species Phoma glomerata and Nigrospora sphaerica were tested at Bangalore, India (Sreerama Kumar et al., 2005). The species were found to be the cause of the sudden decline in $S$. molesta in Bangalore.

\section{Conclusions}

In this review on $E$. crassipes and $S$. molesta, we have shown that both species have serious environmental and socio-economic impacts on equatic ecosystems of the tropics and subtropics (Center, 1987; Room, 1988; Malik, 2007; Villamagna and Murphy, 2009). However the two species and mainly E. crassipes may have a beneficial use in phytoremediation, animal feed and biogas activities (Brix, 1997; Ebel et al., 1997; Zimmels et al., 2006; Xia and Ma, 2006). Improved and large scale utilization of the species could serve as a positive approach to control E. crassipes, especially in the developing countries.

Control mechanisms have had an important impact in controlling the spread of $E$. crassipes, but have been little studied in Africa, especially in the central part. We would agree with Malik (2007), which from the review literature concluded that a holistic approach of the combination of watershed management controlling nutrient supply and integrated biological and herbicidal control seems to offer a viable control option. The ecology of these two species in central Africa remains poorly understood and ecological studies would prove of benefit to fisheries and other industries, particularly as large scale hydroelectric schemes are planned for the Congo basin. 
Table 1. Impacts of E. crassipes and S. molesta on environmemt and human health

\begin{tabular}{|l|c|c|}
\hline \multicolumn{1}{|c|}{ Species } & E. Crassipes & S. molesta \\
\hline $\begin{array}{l}\text { Origin } \\
\text { Reproduction }\end{array}$ & $\begin{array}{c}\text { Amazon (Brazil) } \\
\text { Sexually/Asexually }\end{array}$ & $\begin{array}{c}\text { South-eastern Brazil } \\
\text { Asexually }\end{array}$ \\
$\begin{array}{l}\text { Negative effects on } \\
\text { human health }\end{array}$ & + & +++ \\
$\begin{array}{l}\text { Negative effects on } \\
\text { environment }\end{array}$ & ++++ & \\
Beneficial effects & ++ & +++ \\
Sewage & +++ & +- \\
Phytoremediation and & +++ & ++ \\
Biogas & ++ & + \\
Compost & ++ & + \\
\hline
\end{tabular}

Acknowledgements. Authors wish to thank Hervé Rouhier (Université de Louvain, Belgique) and Kai Sonder (CIMMYT, Texcoco, Mexico) for collecting bibliographic material for this review.

\section{REFERENCES}

[1] Abbasi, S.A., Abassi, N., Bhatia K.K.S. (1997): In: wetlands of India. - Ecology and threats, Vol. III. Discovery Publishing House. New Delhi.

[2] Abbasi, S.A., Ramasamy, E.V. (1999): Biotechnological methods of pollution control. Hyderabad - In : Abbasi, S.S. (ed.) orient Longman (Universities Press of India Ltd) p. 168.

[3] Aweke, G., (1993): Tinth (Eichhornia crassipes) in Ethiopia. - Bulletin des Séances. Académie Royale des Sciences d'Outre-mer. Brussels 39(3): 399-404.

[4] Babu, R.M., Sajeena, A., Seetharaman, K. (2004): Solid substrate for substrate for production of Alternaria alternate conidia: A potential mycoherbicide for the control of Eichhornia crassipes (water hyacinth). - Weed Research 44: 298-304.

[5] Barrett, S.C.H. (1980): Waterweed invasions.- Scientific American. 260: 90-97.

[6] Barrett, S.C.H. (1989): Sexual reproduction in Eichhornia crassipes (water hyacinth). II. Seed production in natural populations. - Journal of Applied Ecology 17: 113-124.

[7] Barreto, R., Charudattan, R., Pomella, A., Hanada, R. (2000): Biological control of neotropical aquatic weeds with fungi - Crop Protection (19): 697-703.

[8] Bolenz ,S., Omran, M., Gierschner, K. (1990):Treatments of water hyacinth tissue to obtain useful products. - Biologycal wastes 33(4): 263-274.

[9] Brendonck, L., Maes, J., Rommens, W., Debeka, N., Nhiwahwa, T., Barson, M., Callebault, V., Crispen, P., Moreau, K., Gratwicke, B., Stevens, M., Alyn, N., Holsters, E., Ollevier, F., Marshall, B. (2003): The impact of water hyacinth (Eichhornia crassipes) in a eutrophic subtropical impoundment (Lake chivero, Zimbabwe). II species diversity. Archive für Hydrobiologie 158: 389-405.

[10] Brix, H. (1997): Do macrophytes play role in constructed treatment wetlands? - Water Science Technology 24(5): 247-253.

[11] Caldelas, C., Iglesia-Turino, S., Araus, J.L., Bort, J., Febrero, A. (2009): Physiological response of Eichhornia crassipes (Mart) Solms to the combined exposure to excess nutrients and Hg. - Brazilian Journal Plant Physiolgy 21(1): 1-12.

[12] Chantiratikul, P., Meechai, P., Nakbanpote, W. ( 2009): Antioxidant activities and phenolic contents of extracts from Salvinia molesta and Eichhornia crassipes. - Research Journal Biological Science 4(10): 1113-1117. 
[13] Center, T.D. (1987): Do waterhyacinth leaf age and ontogeny affect interplant dispersion of neochetina eichhorniae (Coloptera: curculionidae) eggs and larvae? - Environmental Entomology 16: 699-707.

[14] Center T.D. (1994): Biological control of weeds: water hyacinth and water lettuce. - In: by Rosen, D., Bennett, F.D., Capinera, J.L. (eds.) Pest management in the subtropics, biological control - a Florida perspective Intercept LtD, UK, 481-521.

[15] Center, T.D., Dray, F.A, Jubinsky, G., Grodowitz, M.J. (1999): Biological control of water hyacinth under conditions of maintenance management: can herbicides and insects be integrated? -Environmental Management 23: 241-256.

[16] Center, T.D., Van, T.K., Dray, J.F.A., Francks, S.J., Rebelo, M.T., Pratt, P.D., Rayamaghi, M.B. (2005): Herbivory alters competitive interactions between two invasive aquatic plants. - Biological Control 33: 173-185.

[17] Center, T.D., Dray, F.A.J. (2010): Bottom-up control of water hyacinth weevil population: do the plants regulate the insects? - Journal of Applied Ecology 47: 329-337.

[18] Cilliers C.J. 1991. Biological control of water hyacinth, Eichhornia crassipes (Pontederiaceae) in South Africa. - Agriculture. Ecology Environment. (37): 207-217.

[19] Charudattan, R. (1996): Pathogens of Biological control of water hyacinth. - In: Charudattan, R.E., Labrada, R., Center, T.D., Begazo, C.K. (eds.) Strategies for water Hyacinth Control, FAO, Rome pp. 189-196.

[20] Cooke, C.D., Wech, E.B., Petersen, S.A., Newroth P.R. (1993): Restoration and management of lakes and reservoirs. $-2^{\text {nd }}$ Edn Lewis, Publishers, Boca Raton.

[21] Creagh, C. (1992): A marauding weed in check. -Ecosystem Australia. (70): 26-29.

[22] Dada, S.A. (2002): The utilization of water hyacinth (Eichhornia crassipes) by west African dwarf (wad) growing goats. - African Journal of Biomedical Research 4: 147149.

[23] De Groote, H., Ajuanu, O., Attignon, S., Djessou, R., Neuenschwander, P. (2003): Economic impact of biological control of water hyacinth in southern Benin. - Ecological Economy 45: 105-117.

[24] Di Toppi, L.S., Vurro, E., Rossi, L., Marabottini, R., Musetti, R., Careri, M., Maffini, M., Mucchino, C., corradini, C., Badiani, M. (2007): Different compensatory mechanisms in two metal-accumulating aquatic macrophytes exposed to acute cadmium stress in outdoor artificial lakes. - Chemosphère 68: 769-780.

[25] Ebel, M., Evangelou, M.W.H., Schaeffer, A. (2007): Cyanide phytoremediation by water hyacinths (Eichhornia crassipes) - Chemosphère 66: 816-823.

[26] Finlayson, C.M., Farell, T.P., Griffiths, D.J. (1982) Treatment of sewage effluent using water fern salvinia. Water Res. Found. - Australian Report No 57.

[27] Forno, I.W., Harley, K.L.S. (1979): The occurrence of Salvinia molesta in Brazil. Aquatic Botany 6: 185-187.

[28] Gajalakshmi, S., Ramasamy, E.V., Abbasi, S.A. (2002) High rate compostingvermicomposting of water hyacinth (Eichhornia crassipes, Mart. Solms). - Bioresource Technology 83: 235-239.

[29] Gunnarsson ,C.C., Petersen, C.M. (2007): Water hyacinths as a resource in agriculture and energy production: A literature review. - Waste Management. 27: 117-129.

[30] Harley, K.L.S. (1990): The role of biological control in the management of water hyacinth, Eichhornia crassipes. V Biocontrol News Inform. 11: 11-22.

[31] Harley K.L.S., Julien M.H., Wright A.D. (1997). Water hyacinth: a tropical worldwide problem and methods of its control. Proceedings of the first meeting of International Water hyacinth. Consortium - World Bank.

[32] Henry-Silva , G.G., Camargo F.M. (2006): Efficiency of aquatic macrophytes to threat Nile Tilapia ponds effluents. - Science and Agriculture, Piracicaba, Brazil. 63(5): 433438.

[33] Holm, L.G., Plucknett, D.L., Pancho, J.V., Herberger, J.P. (1977): The world's worst weeds: distribution and biology. - University Press of Hawaii, Honolulu. 
[34] Husnar, V.L.M., Caraco, N.F., Roland, F., Cole, J. (2006): Nutrient chlorophyll relationships in tropical lakes: do temperate modes fit? - Biogeochemistry. 79: 239-250.

[35] Jacano C.C. 1999. Salvinia molesta (Salviniaceae), new to Texas and Louisiana. - Sida 18: 927-928.

[36] Julien, M.N., Griffiths, M.W. (1998): Biological control of weeds. A world catalogue of agents and their target weeds. - Fourth and CAB International, Wallingford UK, p 223.

[37] Julien, M.N., Griffths, M.W., Wright, A.D. (1999): Biological control of water hyacinth. The weevils Neochetina bruchi and N. eichhorniae: biologies, host ranges and rearing releasing and monitoring techniques for biological control of Eichhornia crassipes. ACIAR. Monograph 60, 87.

[38] Kammathy, R.V. (1968): Salvinia auriculata. Aublet-a rapidlu spreading exotic weed in Kerala. - Science Culture. 34, 346.

[39] Katerrega, E., Sterner, T. (2007). Indicators for an invasive species water hyacinths in Lake Victoria. - Ecological Indicator 7: 362-370.

[40] Kauraw, L.P., Bhan, V.M. (1994): Efficacity of cassytha powder to water hyacinth and marigold to Parthenium population. - Weed News 1, 3-6.

[41] Kutty, S.R.M., Ngatenah, S.N.I., Isa, M.H., Malakahmad, A. (2009): Nutrients removal from municipal wastewater treatment plant effluent using E. crassipes. World Academy of Science. - Engineer Technology. 60: 826-831.

[42] Lata, N., Veenapani, D. (2010): Eichhornia crassipes a suitable economic feed: the world's worst aquatic weed. - Journal of Food Technology 8(3): 102-105.

[43] Lee, B. (1979): Insects for controlling water weeds. - Rural Ressouces. 105: 25-29.

[44] Leterme, P., Londono, A.M., Ordonez, D.C., Rosales, A., Estrada, F., Bindelle, J., Buldgen, A. (2010): Nutritional value of intake of aquatic ferns (Azolla filiculoides Lam. and Salvinia molesta Mitchell.) in sows. - Animal Feed Science Technology 155: 55-64.

[45] Malik, A. (2007): Environmental challenge vis à vis opportunity: the case of water hyacinth. - Environ. Inter. 33: 122-138.

[46] Mbati G., Neuenchwander P. (2005): Biological control of three floating water weeds, Eichhornia crassipes, Pistia stratotes and Salvinia molesta in the republic of Congo. Biocontrol 50:635-645.

[47] McFarland, D.G., Nelson, L.S., Grodowitz, M.J., Smart, R.M., Owens, C.S. (2004): Salvinia molesta DS Mitchell (giant Salvinia) in the United States: A review of species ecology and approaches to management. Aquatic Plant Control Program. Engineer Research and Development Center. - Washington DC, US, 41p.

[48] Mironga, J.M. (2004): Geographic information systems (GIS) and remote sensing in the management of shallow tropical lakes. - Applied Ecology Environmetal Research. 2(1): 83-103.

[49] Mitchell, D.S., Gopal B. (1991): Invasion of tropical freshwaters by alien aquatic plants. - In: Ramakrishnan, P.S (ed.) Ecology and Biological Invasion of the Tropics. pp 139154.

[50] Olaleye, V.F., Akinyemiju, O.A. (1996): Effect of glyphosate (N(phosphonomethyl)glycine) application to control Eichhornia crassipes Mart. On fish composition and abundance in Abiala Creek. Niger Delta. Nigeria. - Journal of Environmental Management. 47: 115-122.

[51] Oliver, D.J. (1993): A review of biology of giant Salvinia (Salvinia molesta Mitchell). Journal of Aquatic Plant Management. 31: 227-231.

[52] Owens, C.S., Smart, R.M., Stewart, R.M. 2004. Low temperature limits of Salvinia molesta Mitchell. - Journal of Aquatic Plant Management 42: 91-94.

[53] Owens, C.S., Smart, R.M., Honnell, D.R., Dick, G.O. (2005): Effects of the pH on growth of Salvinia molesta Mitchell. - Journal of Aquatic Plant Management 43: 34-38.

[54] Pancho, J.V., Soerjani, M. (1978): Aquatic weeds of southeast Asia. - National Publisher Cooperative. Quezon City. Philippines. 
[55] Room, P.M. (1988): Effects of temperature, nutrients and beetle on branch architecture of the floating weed Salvinia molesta and simulations of biological control. - Journal of Ecology 76: 826-848.

[56] Saxena, M.K. (2000) Aqueous leachate of Lantana camara kills water hyacinth. - Journal of Chemical Ecology. 13: 2435-2447.

[57] Sharma, K.P., Goel, P.K. (1986): Studies on decomposition of two species of Salvinia. Hydrobiologia 131: 57-61.

[58] Scheffer, M., Szabo, S., Cragnani, A. et al. (2003) : Floating plant dominance as a stable state. - Proceedings of the National Academia of Sciences of the United States of America 100: 4040-4045.

[59] Singhal, V., Rai, J.A.N. (2003): Biogas production from water hyacinth and channel grass used for phytoremediation of industrial effluents. - Bioressouces Technology. 86:221225.

[60] Smith, L.W., Williams, R.E., Shaw, M., Green, K.R. (1994): A water hyacinth eradication campaign in New South Wales, Australia. - In: Thyagarajan G. (ed). Proceedings of International conference of water hyacinth. Nairobi UNEP pp 925-935.

[61] Sreerama Kumar, P., Ramani, S., Singh, S.P. (2005): Natural suppression of the aquatic weed S. molesta D.S. Mitchell by two previously unreported fungal pathogens. - Journal of Aquatic Plant Management. 43: 105-107.

[62] Tipping, P.W., Center T.D. (2005): Influence of plant size and species on preference of Cyrtobagous salviniae adult from two populations. - Biological Control 32; 263-268.

[63] Thomas, P.A., Room, P.M. (1986) Taxonomy and control of Salvinia molesta. - Nature 320: 581-584.

[64] Twongo, T., Balirwa, J.S. (1995): The water hyacinth problem and the biological control option in the highland Lake region of the upper Nile basin-Uganda's experience. - The Nile 2002 Conference. Comprehensive water resources development of the Nile basinTaking off. Arusha, Tanzania.

[65] Vandecasteele, B., Quataert, P., Tack, F.M.G. (2005): Effect of hydrological regime on the metal bioavailability for wetland plant species Salix cinerea. - Environmental Pollution 135: 303-312.

[66] Verma, R., Singh, S.P., Ganesha, R.K. (2003): Assessment of changes in water hyacinth coverage of water bodies in northern part of Bangalore City using temporal remote sensing data. - Current Science. 2003, 792-804.

[67] Verma, V.K., Singh, Y.P., Rai, J.P.N. (2007): Biogas production from plant biomass used for phytoremediation of industrial wastes. - BioresourceTechnology 98: 1664-1669.

[68] Villamagna, A.M., Murphy, B.R. (2009): Ecological and socio-economic impacts of invasive water hyacinth (Eichhornia crassipes): a resview. - Freshwater Biology doi:10.1111/j.1365-2427.2009.002294.x

[69] Watson, W.A., Cook, G.S. (1987): Demographic and developmental differences among clones of water hyacinth. - Journal of Ecology 75: 439-457.

[70] Westerdahl, H.E., Getsinger, K.D. (1988): Aquatic plant identification and herbicide use guide Vol. II. Aquatic plants and susceptibility to herbicides technical report 1988. - A88-89-Dpt of the Army, waterways experiment station corps of Engeneers Vicksburg MS.

[71] White, S.E., Tipping, P.W., Becnel, J.J. (2007): First isolation of Helicosporidium sp. (Chlorophyta: Trebouxiophyceae) from the biological control agent Cyrtobagous salviniae (Coleoptera curculionidae) - Biological Control 40: 243-245.

[72] Williams, A.E., Duthie, H.C., Hecky, R.E. (2005) : Water hyacinth in Lake Victoria: why did vanish so quickly will it return. - Aquatic Botany 81: 300-314.

[73] Wilson, J.R., Holst, N., Rees M. (2005): Determinants and patterns of population growth in water hyacinth. - Aquatic Botany 81: 51-67.

[74] Xia, H., Ma, X. (2006): Phytomediation of ethion by water hyacinth (Eichhornia crassipes) from water. - Bioressorces Technology. 97: 1050-1054. 
[75] Zimmels, Y., Kirzhner, F., Malkovskaya, A. (2006): Application of Eichhornia crassipes and Pistia stratiotes for treatment of urban sewage in Israel. - Journal of Environmental Management 81: 420-428. 